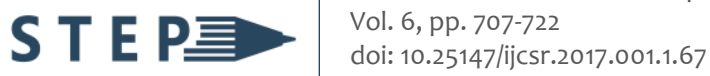 \\ https://stepacademic.net
}

\section{Short Paper \\ Practices of Filipino Public High School Teachers on Digital Teaching and Learning Technologies during the COVID-19 Pandemic: Basis for Learning Action Cell Sessions}

\author{
Babylyn F. Javier \\ SHS Department, Licerio Antiporda Sr. National High School, Cagayan, Philippines \\ babylynfjavier@gmail.com \\ ORCID: 0000-0001-5507-2659
}

Date received: December 21, 2020

Date received in revised form: February 26, 2021

Date accepted: March 16, 2021

Recommended citation:

Javier, B. F. (2022). Practices of Filipino public high school teachers on digital teaching and learning technologies during the COVID-19 pandemic: Basis for learning action cell sessions. International Journal of Computing Sciences Research, 6, 707-722. doi: 10.25147/ijcsr.2017.001.1.67

\begin{abstract}
Purpose - With industry 4.0 revolutionizing the digitally renowned teaching and learning societies, this research study aims to uncover the practices of public high school teachers on digital teaching and learning technologies during the COVID-19 pandemic.

Method - This descriptive-correlational study surveyed 34 consented Filipino teacherparticipants of a public high school system in the Buguey District, Northern Philippines. Validated responses extracted thru Google forms administered in 30 days were described using frequency counts and percentages. Perceived practices were correlated with teacher-participants' profiles, while qualitative key informant interviews disclosed best practices, challenges, and problems along with the use of digital technologies for teaching and learning.
\end{abstract}

Results - Findings revealed rare practices on the use of digital technologies to teaching and learning during the COVID-19 pandemic among teachers which are mostly on early to middle age brackets, dominantly female, completed their equivalent Masters' degree, holding teacher 2 or 3 ranks, and permanently teaching in 6 to 10 years now. Practices of teachers in the use of digital teaching and learning tools are somewhat evident, eager to practice and acknowledging the benefits of using the digital tools and radiating best practices in the workplace. Despite some technical issues that are beyond control, having 
internet at home necessitates the teacher's role to enhance teaching and learning while maximizing the potential of varied tools.

Conclusion - With the onslaught of the COVID-19 pandemic, the Department of Education (DepEd) has indeed necessitated teachers to be innovative in class towards achieving its vision-mission statement by integrating into the curriculum and instruction the use of digital teaching and learning tools.

Recommendations - It is recommended that DepEd must continually upscale its technological competencies with the implementation of the proposed learning action cell sessions.

Research Implications - The relevant research findings provided insights for school administrators for implementing training sessions for teachers to be technologically pandemic-responsive.

Practical Implications - The results of the study provided inputs for teachers to be adaptive to utilizing digital tools for teaching not only in time of a pandemic.

Keywords - COVID-19, digital tools, education, learning, teaching, technologies

\section{INTRODUCTION}

The ever-changing educational perspectives during the COVID-19 pandemic in the different parts of the world have challenged various stakeholders ranging from school administrators, education officials, teachers, students, and parents. Unfolding the 21st century, teaching and learning have particularly been turning the tides considering the fast-paced technological revolution and the growing work environments. Industries and workplaces employ professional, engineers, accountants, teachers, office staffs, and laborers that are at par equipped with not only the competencies from the textbooks, nor the acquired communication, critical and analytical thinking skills, but of the technical skills demanded by the use of various technologies in the workplaces.

Academic institutions, universities, and training institutions are then confronted to boost the totality of an individual from the four corners of the classroom to the actual workplaces. Towards this goal, a blend of contributory factors aid in the holistic development of an individual according to studies. This may range from the quality of an educational system, characteristics of the educational technologies in-place, competencies of the teaching workforce, the dynamism of the support-services, untiring support of the parents, industries, and the community, and more importantly the eagerness of one person to pursue education honing the required skills, competencies, 
and knowledge. New opportunities to further improve the teaching and learning process have been so enormous.

Integration of technology into the learning process brings new opportunities nowadays. Computers indeed have some attributes that, when used correctly, can facilitate student learning (Tuazon, 2019). It offers the ability to provide instruction at any phase, in someplace, and at any pace, thus generating an extremely flexible learning environment whether through providing more interaction with the content or more interaction with other people, computers can support actual learning (Collins \& BronteTinkew, 2010; Courts \& Tucker, 2012). Mandated thru the department's mission, teachers are entrusted to facilitate learning and constantly nurture every learner on various applicable strategies (Tuazon, 2019).

Various studies have already proved the effectiveness of integrating technological advancement in teaching and learning to an individual or student. Various technologies that have been developed and utilized concretely contribute to advancing and improving students' performances. In the field of education, the influence of technology is ever increasing as school districts and even state governments mandate its use more and more each year. Not only in the Buguey School District but the district where the researcher works, all teachers in grades $\mathrm{K}-12$ were also allowed to apply for new technology tools for their classroom. They were offered a SMART Board, an interactive whiteboard; a Liquid Crystal Display (LCD) projector, a projector that connects to a computer hard drive; and an Educators Workstation, a laptop computer with a docking station, and a wireless keyboard and monitor. The district superintendent hoped, by offering these tools as well as training teachers to use the tools, student test scores and both teacher and student motivation would improve. The initiative was made possible due to the Department of Education Computerization Program. The DepEd Computerization Program or DCP aims to provide public schools with appropriate technologies that would enhance the teaching-learning process and meet the challenges of the 21st century (Department of Education, 2013). The objectives of the DCP included (a) provide ICT packages to public schools that are responsive to the needs of the K-12 curriculum; (b) integrate ICT in the teaching and learning process; (c) raise the ICT literacy of learners, pupils, students, teachers, and school heads; (d) improve computer-tostudent ratio in the public schools, and (e) improve the replacement cycle of ICT packages (Department of Education, 2010).

Students should benefit from the use of technology in the classroom. Research in this area has the potential to prove that when teachers use technology tools in the classroom, students become more motivated to learn the material and are more involved in the lesson. In addition, their attention spans may increase when a teacher uses technology tools. Some of these tools include an interactive whiteboard, email, the Internet, coursespecific software, and many other options available today. If teachers understand the importance of integrating technology into their lessons and receive the professional development needed in their fields, they could become accustomed to using technology 
tools; therefore, student learning and motivation could increase. In 2008, Young mentioned Kennedy (2006) stating, "Even if teachers are not drawn to technology, they realize that computers are here to stay, and inevitably, they must resign themselves to developing sufficient technology skills" (p. 43). The readiness of the teachers in the utilization of such technologies in classroom settings is crucial in the organization. This is mainly because the task of doing online learning depends on the skills and competencies the users possess (Javier, 2020; Ventayen, 2019). This study attempted to show that teachers who use technology tools in their classrooms would improve student learning and motivation. "Today's education system faces irrelevance unless we bridge the gap between how students live and how they learn... Students will spend their adult lives in a multi-tasking, multifaceted, technology-driven, diverse, vibrant world-and they must arrive equipped to do so" (Wilson, 2014). Teaching and learning would be best with technology in place (Montealegre, 2019).

During a worldwide COVID-19 pandemic, very limited pieces of literature along teachers' utilization of technologies for teaching and learning in secondary schools could be found in the Philippines. The relevant findings of Fabito, Trillanes, and Sarmiento (2020) confirms both students and faculty members were not fully ready for online learning in this time of pandemic, suggesting a framework for a successful learning experiences for students. The study of (Gorra \& Bhati, 2016) mentioned that fewer articles on this context has been made in the Philippine context, especially in the higher education. It is presumed that less literatures in the secondary high school along this research study has been made available. More often than not, the focused are more of students' use of technology not on teachers. For instance, Balmeo et al. (2014), Garzon, Kim, and Kim, (2019), and Javier and Dirain (2019), highlighted the relationship of using technology in teaching and learning with academic performances of students. Contrastingly, Antonio and Lorenzo (2019) disclosed the high level of adaption and use of ICT in the performance of management functions of administrators. Hence, the study embarked on uncovering the practices of secondary school teachers in the utilization of digital teaching and learning tools. The results of the study would not only add to the growing facet of knowledge but more importantly would provide top-level managers of the public high school sector in the Philippines a concrete view of the real scenario on the ground while benchmarking on the conduct of continuing learning action cell or LAC sessions annually.

This research work generally aimed at determining the practices of public secondary school teachers on teaching and learning technologies during the COVID-19 pandemic, their perceived benefits, challenges, and best practices, as well as the significant relationship between practices and some profile variables. Specifically, the profile of the public secondary school teachers in terms of personal characteristics and their ownership of technology, access to and frequency of internet connection, and general IT skills were described. In addition, the practices of the public high school teachers in the utilization of teaching and learning technologies, the perceived benefits, challenges, and best practices in the use of teaching and learning technologies were accounted for. 
The study was geared towards finding the gaps in the use of digital technologies in teaching and learning (Figure 1) based on the practices, profile, challenges, and perceived benefits of utilizing such. Towards the utilization of the study, a proposed continuing learning action cell or LAC sessions shall be made, and it is hoped that the findings will bear possible professional development initiatives for public school teachers by the Department of Education not only during the COVID-19 pandemic but in the fourth industrial revolution. Hence, a proposed intervention strategy shall be made to handle gaps being identified. A feedback and evaluation mechanism is also important as it affects teaching performances which radiate to the quality of learning amongst learners.

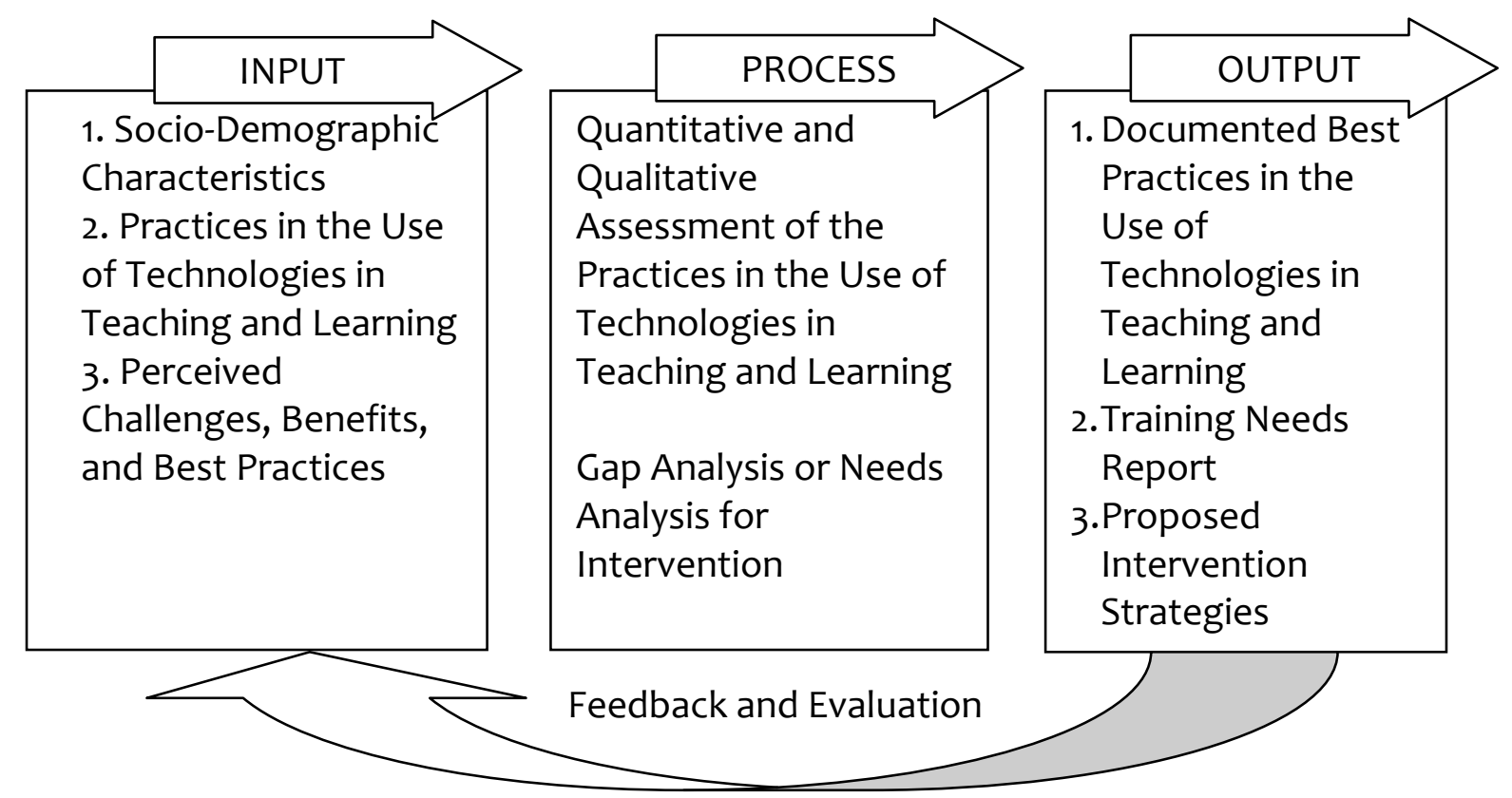

Figure 1. Conceptual Framework

\section{METHODOLOGY}

\section{Research Design}

The research study employed a descriptive survey and correlational design. The profiles of the public secondary school teachers, their practices, as well as qualitative data on benefits, challenges, and best practices were collected. Select profile variables have been correlated with their practices.

\section{Participants}

The participants of the study are public high school teachers in the schools' division of Cagayan, Buguey Educational District. All 3 public high schools in the district were considered as part of the population. Responses were elicited from the 63 high school teachers with approved consent from authorities and the school heads respectively. Random sampling was made based on the listing shared with the researcher. 


\section{Data Collection Tools and Techniques}

The main tool used in this study was a validated survey questionnaire consisting of the participants' profile, ownership of devices, access to the Internet, and their IT skills. It also covered their practices in the utilization of inline teaching tools which are extracted from the literature. The survey questionnaire has undergone content validity by 3 experts. A test-retest method was also conducted to measure the reliability of the questionnaire. After seeking formal consent from authorities and school heads, the researcher formally administered the survey. In full compliance with COVID-19 InterAgency Task Force or IATF protocols, the researcher maximized the use of Google Forms for administering the questionnaire online. Formal consent to be part of the study was first presented and permission to participate was sought from all the teacher-participant. The survey questionnaire was made available to all targeted participants in 30 days, not allowing multiple responses. A follow-up is made through email every after three days. The collection period was established in the months of August to October 2020. An openended survey-based inquiry was used to elicit best practices shared by the participants.

\section{Data Analysis}

The individual and summary of the responses were exported from Google Forms and extracted as comma-separated values or CSV files. The participants' responses were then subjected for review and validation. Each teacher-participant was consulted of their responses. Each validated response was than updated in the summary table. The validated summary table was then subjected to applicable statistical treatment via Statistical Package for Social Science version 21 and Microsoft Excel Data Analysis Tool Pack. Responses along the teachers' practices involving a 5-point Likert Scale were interpreted with 5 as Always through 1 as Never. Frequency counts, percentages, ranks, and weighted means were used. Responses to open-ended survey-based inquiry on the participant's best practices were deduced through simple thematic analysis. Responses were analyzed until themes were extracted.

\section{RESULTS}

\section{Personal Characteristics of the Teacher - Participants}

The study generally aimed to obtain the responses of all the senior and junior high teachers in the Buguey Educational District. However, only 34 teachers participated and all with valid responses. Tables 1 and 2 present the profile of the teacher-participants. 


\begin{tabular}{|c|c|c|c|c|}
\hline Variable & Category & $F(n=34)$ & $\%$ & Cumulative \% \\
\hline \multirow{5}{*}{ Age } & $21-30$ & 13 & 38.24 & 38.24 \\
\hline & $31-40$ & 13 & 38.24 & 76.47 \\
\hline & $41-50$ & 5 & 14.71 & 91.18 \\
\hline & $51-60$ & 2.0 & 5.88 & 97.06 \\
\hline & above 60 & 1.0 & 2.94 & 100 \\
\hline \multirow[b]{2}{*}{ Sex } & Female & 30 & 88.2 & 88.2 \\
\hline & Male & 4 & 11.8 & 100.0 \\
\hline \multirow{3}{*}{ Civil Status } & Married & 22 & 64.7 & 64.7 \\
\hline & Single & 11 & 32.4 & 97.1 \\
\hline & Widowed & 1 & 2.9 & 100.0 \\
\hline \multirow{2}{*}{$\begin{array}{l}\text { Highest Education } \\
\text { Attained }\end{array}$} & BS Degree & 8 & 23.5 & 23.5 \\
\hline & Masters' Degree & 26 & 76.5 & 100.0 \\
\hline \multirow[b]{2}{*}{ Classification } & Junior HS & 19 & 55.9 & 55.9 \\
\hline & Senior HS & 15 & 44.1 & 100.0 \\
\hline \multirow{7}{*}{ Teaching Rank } & Teacher 1 & 6 & 17.65 & 17.65 \\
\hline & Teacher 2 & 13 & 38.24 & 55.88 \\
\hline & Teacher 3 & 11 & 32.35 & 88.24 \\
\hline & Special Science Teacher 1 & 1 & 2.94 & 91.18 \\
\hline & Master Teacher 1 & 1 & 2.94 & 94.12 \\
\hline & $\begin{array}{l}\text { Secondary School } \\
\text { Principal } 3\end{array}$ & 1 & 2.94 & 97.06 \\
\hline & Probationary & 1 & 2.94 & 100 \\
\hline \multirow{3}{*}{ Employment Status } & Contractual & 2 & 5.9 & 5.9 \\
\hline & Permanent & 31 & 91.2 & 97.1 \\
\hline & Probationary & 1 & 2.9 & 100.0 \\
\hline \multirow{5}{*}{ Years in Teaching } & less than 6 years & 11 & 32.35 & 32.35 \\
\hline & $6-10$ Years & 9 & 26.47 & 58.82 \\
\hline & $11-15$ Years & 5 & 14.71 & 73.53 \\
\hline & $16-20$ years & 5 & 14.71 & 88.24 \\
\hline & above 20 years & 4 & 11.76 & 100.00 \\
\hline
\end{tabular}


The plurality of the participants both belongs to age brackets 21 to 30 and 31 to 40 years of age (76.48\%), a majority representing vibrancies and vigor in the teaching and learning process. A substantial percentage (88.2\%) was female, outnumbering their male counterpart. This is a common scenario in the public educational system in the Philippines. Meanwhile, a majority of the participants or 64.7 percent were married, while 11.8 percent are single. Getting into a teaching position in the Department of Education requires relevant academic preparation to fit in the teaching profession. Fortunately, the majority or 26 participants obtained their equivalent master's degree, higher than a handful or 8 teacher-participants with bachelor's degrees. With the implementation of the K-12 curriculum of the Department of Education, the senior high school teaching positions were created. Since 2016, most if not all, public high schools were classified into two: junior and senior. In this study, most of the participants (55.9\%) have been teaching at the junior level, while 44.1 percent are in senior high school. With the senior high school in the K12 curriculum being implemented, it's not surprising that the bulk of the participants (38.4\%) hold a Teacher 2 rank, while the remaining percentage holds the teaching ranks Teacher $1(17.65 \%)$ and Teacher $3(32.35 \%)$. Almost all of the participants are permanent (91.2\%), except those under probation, and contractual positions. While most of the participants have been teaching passionately for decades, the majority of the responses showed an ample percentage teaching for less than 6 years (32.35), and some 6 to 10 years $(26.47 \%)$.

It is not surprising that all teacher-participants have an internet-enabled mobile phone (Table 2). The necessity of such technology is crucial to making communications, as well as profession-related usage. The responses were taken at the height of COVID-19 quarantine implementation nationwide. Also, nearly all or 97.1 percent have with them a laptop or a desktop to use in teaching and professional activities. With the DepEd Computerization Program, internet connectivity becomes a crucial driver to the teaching and learning process in the Philippines (DepEd, 2010). Philippines may have been lagging behind neighboring countries in the ASEAN region along with internet speed, but Filipino resilience may have brought forth the way Filipinos are on top as a global leader in social networking i.e. Facebook usage. Whether in school or at home, it is noteworthy to emulate that most teachers have internet connections, in school (61.8\%) and at home (73.5\%). The finding is a positive manifestation of the necessity for internet connectivity despite being confronted with poor internet infrastructure status in the countryside. Meanwhile, a substantial percentage (88.2\%) accesses the internet daily via their mobile phones. This coincides with the fact that all teacher-participants have internet-abled mobile phones, including the availability of internet connection. While a handful accesses the Internet via laptop on a weekly and monthly basis, a significant number or 20 teacherparticipants access the net via laptop or desktop. With the availability of internet connection, devices, and/or equipment, it is not surprising that most of the teacherparticipants have been using the Internet for 5 years or more. With the above data, teacher-participants assessed their ICT skills generally good with 28 teacher-participants responding. General ICT skills in this context refer to the capacity of the participants to 
utilize ICT tools and applications for teaching, socializing, communicating, and doing basic transactions with the Internet.

Table 2. Connectivity and Access to the Internet

\begin{tabular}{|c|c|c|c|c|}
\hline Variable & Category & $f(n=34)$ & $\%$ & Cumulative \% \\
\hline \multirow[t]{2}{*}{ With Mobile phone Internet-enabled } & Yes & 34 & 100.00 & 100.00 \\
\hline & No & 0 & 0.00 & \\
\hline \multirow[t]{2}{*}{ With Laptop or Desktop } & Yes & 33 & 97.1 & 97.10 \\
\hline & No & 1 & 2.9 & 100.0 \\
\hline \multirow[t]{2}{*}{ With Internet Connection in School } & Yes & 21 & 61.8 & 61.80 \\
\hline & No & 13 & 38.2 & 100.00 \\
\hline With an Internet connection at & Yes & 25 & $73 \cdot 5$ & $73 \cdot 50$ \\
\hline Home & No & 9 & 26.5 & 100.0 \\
\hline Freq of Access to the Internet via & Daily & 30 & 88.2 & 88.20 \\
\hline Mobile Phone & Weekly & 4 & 11.8 & 100.0 \\
\hline Freq of Access to the Internet via & Daily & 20 & 58.8 & 58.8 \\
\hline \multirow[t]{3}{*}{ Laptop/Desktop } & Weekly & 6 & 17.6 & 76.5 \\
\hline & Monthly & 6 & 17.6 & 94.4 \\
\hline & Never & 2 & $5 \cdot 9$ & 100.0 \\
\hline \multirow[t]{4}{*}{ Years using the Internet } & Less than a year & 1 & 2.9 & 2.9 \\
\hline & 1 to 2 years & 1 & 2.9 & $5 \cdot 9$ \\
\hline & 3 to 4 years & 4 & 11.8 & 17.6 \\
\hline & 5 years or more & 28 & 82.4 & 100.0 \\
\hline \multirow[t]{3}{*}{ General ICT Skills } & Acceptable & 1 & 2.9 & 2.9 \\
\hline & Good & 28 & 82.4 & 85.3 \\
\hline & Excellent & 5 & 14.7 & 100.0 \\
\hline
\end{tabular}


Table 3. Practices of High School Teachers with Online Teaching and Learning Tools

PRACTICES
1. I am fond of collaborating with students through
social networking group activities.
$2 . \quad$ I require students to make their own engaging and
interactive web content on a case study.

Mean discussions at least once a month.

5. I collaborate with other teachers online to improve my teaching and learning competencies.

6. I oblige my students to use vlogging, podcasts, and interactive live-chats on certain case analyses or requirements.

7. I am confident that students acquired the necessary competencies when teachers are open to using varying education 4. Tools.

8. I use Google Forms, SurveyMonkey, Mentimeter, and Facebook polls to elicit opinions and spur discussions.

9. Using presentation packages insinuates learners' interests.

10. I require students to maintain their student portfolios.

11. Visual contents are better illustrated by the students especially increasing creativity.

12. I would not end the day without leaving coursework to my students via Edmodo, Google Classrooms, and Kahoot. 13. I monitor wikis and blogs using education 4.0 tools efficiently

14. The 4Cs of the digital economy are honed using collaborative education 4.0 tools like YouTubeEdu, FB Workplace, and Facebook Chat.

15. I monitor students' performance using education 4.0 tools.

Weighted Mean
W.

2.32

1.82

2.21

2.18

Verbal Interpretation

Rarely Practiced

Rarely Practiced

Rarely Practiced

Rarely Practiced

2.04 Rarely Practiced

1.98 Rarely Practiced

2.6 Rarely Practiced

3.52

3.62

2.04

2.26

2.24

Rarely Practiced

2.14 Rarely Practiced

2.65 Often Practiced

4.02

Sometimes

Practiced

2.51 Rarely Practiced 


\section{Current Practices of High School Teachers with Online Teaching and Learning Tools}

This study focused more on documenting the current practices of public high school teachers on educational teaching and learning tools. Teachers' use of digital teaching and learning tools was rarely practiced with an overall weighted mean of 2.502 (S.D.=1.29) as presented in Table 3. With the blend in age among the participants, the use of presentation packages to insinuate learner's interest was assessed "sometimes practiced" with a mean of 3.62 (S.D.=0.551). This could be attributed to the fact that more teacher-participants in this study are in their early teaching years. Often practiced, the participants maximized collaborative education tools like YouTubeEdu, FB Workplace, and Facebook Chat to honing the $4 \mathrm{Cs}$ of the digital economy with a mean of 2.65 ( $\mathrm{S}$. $\mathrm{D}=1.152$ ). Most of the digital teaching and learning tools were rarely maximized by the public high school teachers. This is attributed to the challenges in the use of digital teaching and learning tools (Montealegre, 2019).

\section{Perceived Benefits, Challenges, and Best Practices in the Use of Digital Teaching and Learning Tools}

The teacher-participants also disclosed how does the use of digital teaching and learning tools benefits them as teachers. Ranking the consolidated responses, a substantial percentage (88.24\%), as presented in Table 4, said "it makes the teaching and learning exciting", followed by "Students are engaging in the class" and "Students become proactive and creative". This implies that while teaching with technologies fulfilled the role of the teacher, the student's involvement is heightened by the integration of digital learning tools.

Table 4. Perceived Benefits of using Digital Teaching and Learning Tools

\begin{tabular}{lcc}
\hline & $\mathbf{f}(\mathbf{n = 3 4})$ & Rank \\
\hline 1. It makes teaching and learning exciting. & 30 & 1 \\
2. Students are engaging in the class. & 29 & 2 \\
3. Students become proactive and creative. & 25 & 3 \\
4. It adds pride to being proficient or knowledgeable in using ICT & 22 & 4 \\
tools & 20 & 5 \\
5. Improved my technical competencies as a teacher & 18 & 6 \\
6. Convenient and easy to manipulate. & 14 & 7 \\
7. It is portable and widely available from the Internet & 10 & 8 \\
8. Teachers discovers new methodologies and strategies & & \\
\hline
\end{tabular}

But with the integration of such digital teaching and learning tools, are the challenges that hampered teacher-participants in utilizing technologies in classroom settings. All responses accorded to internet connectivity issues in the area, both among students and teachers. Meanwhile, some 25 participants need more mentoring or training to fully grasp the use of such teaching and learning technologies as seen in Table 5. Also, they err on the attention being posted by students, especially on discussions. 
Table 5. Perceived Challenges in using Digital Teaching and Learning Tools during COVID-19 pandemic

\begin{tabular}{lcc}
\hline & $\mathbf{f}$ & Rank \\
$(\mathbf{n = 3 4 )}$ & 34 & 1.5 \\
1. Internet connectivity issues in the area & 34 & 1.5 \\
2. Not all students have access to the Internet & 25 & 3 \\
3. Needs more mentoring or training to fully grasps the use of & \multicolumn{2}{c}{4} \\
such tools & 20 & 5 \\
4. Students are not more engaging in discussions, attention & 19 & 6.5 \\
spans are short & 18 & 6.5 \\
5. Teachers carry the burden of the Internet connection cost & 18 & 8 \\
6. Lack of school-based ICT equipment per class & 15 & \\
7. Not all teachers are updated with technologies & & \\
8. Many preparations of contents presentations & &
\end{tabular}

\section{Best practices from teacher-participants}

From the open-ended survey questions validated thru phone interview, teachers illustrated their practices in class that is worth emulating, thus this part documents the best practices of teachers in using digital teaching and learning tools. Responses were thematically analyzed drawing the following:

(a) collaboration with co-teachers,

(b) mentor-a-co-student scheme for students having a hard time in the use of technologies,

(c) joining discussions rooms made by DepEd teachers,

(d) self-paced learning and practice,

(e) use of combination tools in teaching and learning, and

(f) mentoring or tutoring via LAC sessions.

\section{Relationship between practices in the use of digital teaching and learning tools to select profile variables}

Apparent in the table that years in using the internet is significantly related indirectly to practices in using digital teaching and learning technologies among the teachers as signified by the coefficient of -.464 with an associated probability of .006 . This means that have been using the Internet for years, teachers tend not to fully put into practice the use of digital teaching and learning tools. This could be attributed to the perceived challenges having been experienced by the teachers.

Evident in the same table (Table 6) that having an Internet connection at home is significantly related to the teachers' practices $(r=0.447, p<0.05)$. This means that with ease of access to the Internet at home, the more the teachers could practice the use of digital teaching and learning technologies. The findings are attributed to the number of applications the teachers used presented in the prior tables. The findings agree with Liu (2016) that access to technology like internet connection influences the use of applications and technologies. 
Table 6. Relationship between practices and select profile variables

\begin{tabular}{cccc}
\hline Variable & $\begin{array}{c}\text { Correlation } \\
\text { Coefficient }\end{array}$ & Prob. & $\begin{array}{c}\text { Statistical } \\
\text { Inference }\end{array}$ \\
\hline Years using the Internet & $-0.464^{* *}$ & .006 & $\mathrm{~S}$ \\
Having the Internet at home & $0.447^{* *}$ & .008 & $\mathrm{~S}$ \\
Access to the Internet via Mobile Phone & $0-.416^{*}$ & .014 & $\mathrm{~S}$ \\
Access to the Internet via PC or Laptop & $-0.466^{* *}$ & .006 & $\mathrm{~S}$ \\
HS Classification & 0.059 & .739 & $\mathrm{NS}$ \\
Age & 0.133 & .455 & $\mathrm{NS}$ \\
Years in Teaching & -0.113 & .526 & $\mathrm{NS}$ \\
General ICT Skills & 0.271 & .122 & $\mathrm{NS}$ \\
Ownership of PC or Laptop & -0.241 & .169 & $\mathrm{NS}$ \\
\hline
\end{tabular}

Accessing the Internet thru mobile phones and laptops or personal computers showed an indirect significant relationship to the teachers' practices in using digital teaching and learning technologies. The relationship with a coefficient of -.416 with an associated probability of 0.14 and a coefficient of -.466 with an associated probability of .006 significantly suggest that while teachers have access thru mobiles and laptops, still they failed to practice the use of digital technologies to teaching and learning. The findings agree with Ertmer et al. (2012) suggesting that the strongest barriers preventing other teachers from using technology were their existing attitudes and beliefs toward technology, as well as their current levels of knowledge and skills.

\section{Proposed Action Plan for the Public High School Teachers of Buguey District}

Upscaling the competencies of the public high school teachers to address certain gaps and share best practices especially in an educational pandemic, the proposed action plan is presented. The skills of the teachers in utilizing the different tools for teaching and learning will be improved, thus radiating resiliency in teaching and learning amidst pandemic with digital technologies. 
Table 7. Proposed Action Plan for the Public High School Teachers*

\begin{tabular}{|c|c|c|}
\hline Activity & Target Date & People Involved \\
\hline $\begin{array}{l}\text { Communication and Coordination } \\
\text { Activities with DepEd officials }\end{array}$ & March 2021 & $\begin{array}{l}\text { Researcher, DepEd } \\
\text { authorities }\end{array}$ \\
\hline $\begin{array}{l}\text { Presentation of Study Results to } \\
\text { Authorities and Action plan }\end{array}$ & April 2021 & $\begin{array}{l}\text { Researcher, DepEd } \\
\text { authorities }\end{array}$ \\
\hline $\begin{array}{l}\text { Coordination and Training Scheduling } \\
\text { for High Schools }\end{array}$ & May 2021 & $\begin{array}{l}\text { Researcher, DepEd } \\
\text { authorities }\end{array}$ \\
\hline $\begin{array}{l}\text { Virtual LAC Session 1: Tools for } \\
\text { Communication for Teachers and } \\
\text { Students }\end{array}$ & July 2021 & $\begin{array}{l}\text { All teachers, } \\
\text { Researcher, Deped } \\
\text { Officials }\end{array}$ \\
\hline $\begin{array}{l}\text { Virtual LAC Session 2: ICT tools for } \\
\text { blended learning }\end{array}$ & July 2021 & $\begin{array}{l}\text { All teachers, } \\
\text { researcher, Deped } \\
\text { Officials }\end{array}$ \\
\hline $\begin{array}{l}\text { Virtual LAC Session 3: Education } 4.0 \\
\text { for Classroom Management }\end{array}$ & July 2021 & $\begin{array}{l}\text { All teachers, } \\
\text { Researcher, DepEd } \\
\text { authorities }\end{array}$ \\
\hline $\begin{array}{l}\text { Virtual LAC Session 4: Office } \\
\text { Productivity for Teachers and Students }\end{array}$ & July 2021 & $\begin{array}{l}\text { All Teachers, } \\
\text { Researcher, DepEd } \\
\text { authorities }\end{array}$ \\
\hline $\begin{array}{l}\text { Virtual LAC Session 5: Collaboration } \\
\text { and Creation Tools for Learning }\end{array}$ & August 2021 & $\begin{array}{l}\text { All Teachers, } \\
\text { Researcher, DepEd } \\
\text { authorities }\end{array}$ \\
\hline $\begin{array}{l}\text { Virtual LAC Session 6: Assessment } \\
\text { and Use of OER }\end{array}$ & August 2021 & $\begin{array}{l}\text { All Teachers, } \\
\text { Researcher, DepEd } \\
\text { authorities }\end{array}$ \\
\hline Evaluation and Feedback & August 2021 & $\begin{array}{c}\text { All Teachers, } \\
\text { Researcher, DepEd } \\
\text { authorities }\end{array}$ \\
\hline
\end{tabular}

*subject to adjustment adopting the DepEd Calendar

\section{CONCLUSIONS AND RECOMMENDATIONS}

It is concluded that practices among teachers in the use of digital teaching and learning tools during the COVID-19 pandemic are somehow evident, eager to practice the use and benefitting from using the tools and radiating best practices in the workplace. Despite some technical issues that are beyond control and the challenges of the COVID-19 pandemic, having an Internet connection at home necessitates the teacher's role to enhance teaching and learning while maximizing the potential of varied tools. With the onslaught of the COVID-19 pandemic, DepEd has indeed necessitated teachers to be innovative in class towards achieving its vision-mission statement by integrating into the curriculum and instruction the use of digital teaching and learning tools. 
It is recommended that DepEd should provide opportunities to continually upscale the technological competencies of its teachers with the implementation of the proposed learning action cell sessions. The relevant research findings provided insights for school administrators for implementing training sessions for teachers to be technologically pandemic-responsive. The results of the study provided inputs for teachers to be adaptive to utilizing digital tools for teaching not only in time of a pandemic.

\section{REFERENCES}

Antonio, V., \& Lorenzo, N. (2019). Ilocano Administrators' Adoption and Use of ICT in the Management of Public Secondary Schools. Asia Pacific Journal of Multidisciplinary Research, 7(2), 1-15. Retrieved January 2020, from http://www.apjmr.com/wpcontent/uploads/2019/05/APJMR-2019.7.2.2.01.pdf

Balmeo, M., Nimo, E., Pagal, A., Puga, S., Quino, A., \& Sanwen, J. (2014). Integrating Technology in Teaching Students with Special Learning Needs in the SPED schools in Baguio City. The IAFOR Journal of Education, 2(2), article 5. Retrieved March 2020, from http://iafor.org/archives/journals/iafor-journal-ofeducation/10.22492.ije.2.2.05.pdf

Collins, A., \& Bronte-Tinkew, J. (2010). Incorporating technology into out-of-schooltime programs: Benefits, challenges, and strategies. Child Trends.

Courts, B., \& Tucker, J. (2012). Using technology to create a dynamic classroom experience. Journal of College Teaching and Learning, 9(2), 121-128.

Department of Education. (2013). DepEd Order No. 36, s.2013. Retrieved March 2020, from Department of Education Web Site: www.deped.gov.ph

DepEd. (2010). Guidelines on the implementation of the DepEd Computerization Program. Retrieved March 2020, from Department of Education: www.deped.gov.ph

Ertmer, P. A., Ottenbreit-Leftwich, A. T., Sadik, O., Sendurur, E., \& Sendurur, P. (2012). Teacher beliefs and technology integration practices: A critical relationship. $\begin{array}{llll}\text { Computers } \quad \& \quad \text { Education, } & \text { 59(2), }\end{array}$ doi:https://doi.org/10.1016/j.compedu.2012.02.001

Fabito, B. S., Trillanes, A. O., \& Sarmiento, J. (2020). Barriers and challenges of computing students in an online learning environment: Insights from one private university in the Philippines. International Journal of Computing Sciences Research, 5(1), 441-458. doi: 10.25147/ijcsr.2017.001.1.51

Garzon, J., Kim, N., \& Kim, C. (2019). Relationship of Facebook use and scholastic performance: The case of Filipino senior high school students. Asian Journal of Education and e-Learning, 7(1), 48-55.

Gorra, V. C., \& Bhati, S. (2016). Students' perception on use of technology in the classroom at higher education institutions in Philippines. Asian Journal of Education and e-Learning, 4(3), 92-103. Retrieved March 2020, from https://ro.uow.edu.au/cgi/viewcontent.cgi?article=1878\&context=buspapers

Javier, B. S. (2020). Organizational e-learning readiness in a state university in northern Philippines: Inputs for refining instructional quality. Test Engineering and Management, 82(January-February), 5560-5569. Retrieved April 2020, from http://www.testmagzine.biz/index.php/testmagzine/article/view/1711

Javier, B. S., \& Dirain, E. L. (2019). Edmodo as supplemental tool blended learning: The case of Filipino university students. International Journal of Science and Research, 8(6), 352-357. doi:10.21275/ART20198368

Liu, P. (2016). Technology integration in elementary classrooms: Teaching practices of student teachers. Australian Journal of Teacher Education, 41(3), 87-104.

Montealegre, M. A. (2019). Education 4.0: Rebooting Phl teacher education. Retrieved February 2020, from PhilStar global: https://www.philstar.com/othersections/education-and-home/2019/07/28/1938565/education-40-rebooting-phl- 
teacher-education

Tuazon, I. M. (2019). Implementation of the DepEd Computerization Program for Indigenous Peoples. Asian Journal of Educational Research, 7(1), 1-14. Retrieved March 2020, from http://multidisciplinaryjournals.com/wpcontent/uploads/2019/02/Full-Paper-IMPLEMENTATION-OF-DepEdCOMPUTERIZATION-PROGRAM-DCP-FOR-THE.pdf

Ventayen, R. J. (2019). Educators competencies on the application of technological tools in teaching. International Journal of Scientific \& Technology Research, 8(11), 907-912. Retrieved March 2020, from http://www.ijstr.org/final-print/nov2019/EducatorsCompetencies-On-The-Application-Of-Technological-Tools-In-Teaching-.pdf

Wilson, K. B. (2014). Impact of emerging technologies on teacher education: Experience of teacher-trainees. Journal of Education and Practice, 5(28), 168-175.

Young, R. (2008). Using technology tools in the public school classroom. Menomonie, WI: University of Wisconsin-Stout. Retrieved March 2020, from http://www2.uwstout.edu/content/lib/thesis/2008/2008youngr.pdf

\section{Author's Biography}

Babylyn F. Javier is currently a Secondary School Teacher 3 at the Licerio Antiporda Sr. National High School in the Buguey educational district, Division of Cagayan, Philippines. She completed academic units in MS Information Technology and a graduate of Master of Science in Teaching at St. Paul University Philippines. She shares her experiences and skills within and outside her institution through professional talks, pieces of training, and seminars related to ICT in education. She likewise attends the same for professional growth. 